\title{
Tailoring the surface structures of iron oxide nanorods to support Au nanoparticles for $\mathrm{CO}$ oxidation
}

\author{
Wen Shi a,c,t, Tongtong Gao a,b,t, Liyun Zhang a, Yanshuang Ma a , Zhongwen Liu b,*, Bingsen Zhang a,\# \\ a Shenyang National Laboratory for Materials Science, Institute of Metal Research, Chinese Academy of Sciences, Shenyang 110016, Liaoning, China \\ b Key Laboratory of Applied Surface and Colloid Chemistry, Ministry of Education, School of Chemistry \&Chemical Engineering, Shaanxi Normal University, \\ Xi'an 710119, Shaanxi, China \\ c School of Materials Science and Engineering, University of Science and Technology of China, Hefei 230026, Anhui, China
}

\section{A R T I C L E I N F O}

\section{Article history:}

Received 2 March 2019

Accepted 6 April 2019

Published 5 December 2019

\section{Keywords:}

Iron oxide nanorods

Surface property

Au nanoparticle

CO oxidation

Structure evolution

\begin{abstract}
A B S T R A C T
Iron oxide supported Au nanomaterials are one of the most studied catalysts for low-temperature $\mathrm{CO}$ oxidation. Catalytic performance not only critically depends on the size of the supported $\mathrm{Au}$ nanoparticles (NPs) but also strongly on the chemical nature of the iron oxide. In this study, Au NPs supported on iron oxide nanorods with different surface properties through $\beta$ - $\mathrm{FeOOH}$ annealing, at varying temperatures, were synthesized, and applied in the CO oxidation. Detailed characterizations of the interactions between Au NPs and iron oxides were obtained by X-ray diffraction, transmission electron microscopy (TEM), and X-ray photoelectron spectroscopy. The results indicate that the surface hydroxyl group on the $\mathrm{Au} / \mathrm{FeOOH}$ catalyst, before calcination $(\mathrm{Au} / \mathrm{FeOOH}-$ fresh), could facilitate the oxygen adsorption and dissociation on positively charged $\mathrm{Au}$, thereby contributing to the low-temperature $\mathrm{CO}$ oxidation reactivity. After calcination at $200{ }^{\circ} \mathrm{C}$, under air exposure, the chemical state of the supported Au NP on varied iron oxides partly changed from metal cation to $\mathrm{Au}^{0}$, along with the disappearance of the surface $\mathrm{OH}$ species. $\mathrm{Au} / \mathrm{FeOOH}$ with the highest $\mathrm{Au}^{0}$ content exhibits the highest activity in $\mathrm{CO}$ oxidation, among the as-synthesized catalysts. Furthermore, good durability in $\mathrm{CO}$ oxidation was achieved over the $\mathrm{Au} / \mathrm{FeOOH}$ catalyst for $12 \mathrm{~h}$ without observable deactivation. In addition, the advanced identical-location TEM method was applied to the gas phase reaction to probe the structure evolution of the $\mathrm{Au}$ /iron oxide series of the catalysts and support structure. A Au NP size-dependent Ostwald ripening process mediated by the transport of $\mathrm{Au}(\mathrm{CO})_{x}$ mobile species under certain reaction conditions is proposed, which offers a new insight into the validity of the structure-performance relationship.
\end{abstract}

(C) 2019, Dalian Institute of Chemical Physics, Chinese Academy of Sciences. Published by Elsevier B.V. All rights reserved.

\section{Introduction}

For high catalytic efficiency at low temperatures, Au nano- particles (NPs) supported on metal oxides have generally been used to catalyze an increasing number of reactions [1], since they were used for the first time in the low-temperature CO

\footnotetext{
* Corresponding author. Tel: +86-29-81530801; Fax: +86-29-81530727; E-mail: zwliu@snnu.edu.cn

\# Corresponding author. Tel: +86-24-83970027; Fax: +86-24-83970019; E-mail: bszhang@imr.ac.cn

† These authors contributed equally to this work.

This work was supported by the National Natural Science Foundation of China $(21773269,21761132025,91545119,21703262)$, the Youth Innovation Promotion Association CAS (2015152), and the Joint Foundation of Liaoning Province Natural Science Foundation and Shenyang National Laboratory for Materials Science (20180510047).

DOI: S1872-2067(19)63374-7 | http://www.sciencedirect.com/science/journal/18722067 | Chin. J. Catal., Vol. 40, No. 12, December 2019
} 
oxidation by Haruta et al. [2] in 1987. It was found that catalytic performance is strongly influenced by the size of the Au NPs, the valence states of the Au species, and the nature of the support material, as well as the preparation method and activation procedure of the catalysts [3-7]. For instance, CO oxidation is found to be sensitive to the size of the Au NPs. Generally, Au NPs with optimal particle sizes in the range of 1-3 nm are critical to the high catalytic activity [8-14]. Moreover, some studies reported that the deposition-precipitation method produces more active $\mathrm{Au} / \mathrm{Fe}_{2} \mathrm{O}_{3}$ catalysts in $\mathrm{CO}$ oxidation than conventional impregnation [15]. Notably, the metal oxide support may play the most important role in the remarkable catalytic activity of Au NPs [16]. In the past decade, extensive attention was focused on the Au catalysts using reducible metal oxides as supports (e.g., $\mathrm{TiO}_{2}, \mathrm{CeO}_{2}, \mathrm{Fe}_{2} \mathrm{O}_{3}$, etc.) due to their capability to generate strong metal-support interactions (SMSI) or provide reactive oxygen for the rational design of catalysts with high efficiencies [17-19]. Iron oxide is one of the most widely used transition metal oxides for Au NPs support, due not only to its excellent performance and abundance but also to the new reaction pathways that it can provide [20-27]. In spite of numerous research works devoted to uncovering the origin of the unexpectedly high activity of iron oxide supported Au catalysts [28], the metal-support interfacial interactions and the role of the surface properties of iron oxide in the reaction mechanism are still under debate [29-33].

Currently, there are many research works focused on unraveling the active sites of catalysts and the reaction mechanisms in CO oxidation [27,34-35], while few papers on the influence of the surface structure of iron oxide on the dispersion as well as the stability of Au NPs, have been reported. However, the surface nature of the iron support would play an important role in the CO oxidation, due to the different possible sites to anchor metal NPs and further tailor the catalytic behavior. To obtain accurate structure-activity relationships of the iron oxide supported $\mathrm{Au}$ catalysts, it is necessary to systematically study the role of the surface structure of iron oxide in CO oxidation.

In this study, iron oxide nanorods with different surface properties were synthesized by calcination of the $\beta$-FeOOH precursor at different temperatures and further used as supports for $\mathrm{Au}$ NPs to obtain a $\mathrm{Au}$ /iron oxide series of catalysts through a urea coprecipitation process. The correlation between the iron oxides with varied surface properties and the supported Au NPs in CO oxidation was established. Furthermore, the structure evolution of the iron oxide supported $\mathrm{Au}$ NPs catalysts during the CO oxidation was studied by the gas-phase identical location transmission electron microscopy (IL-TEM). By comparing and quantifying a series of TEM images, the behavior of supported Au NPs and the structure evolution of the catalysts related to the surface properties were explored in detail.

\section{Experimental}

\subsection{Support synthesis}

$\beta$-FeOOH nanorods, the precursor for different iron oxide supports, were obtained by coprecipitation, as previously reported by our group [36]. $\mathrm{FeCl}_{3} \cdot 6 \mathrm{H}_{2} \mathrm{O}$ (1.35 g), carbamide (750 $\mathrm{mg}$ ), sodium chloride (2.9 g), and polyethylene glycol (PEG: 2.5 $\mathrm{mL}$ ) were dissolved in a $100 \mathrm{~mL}$ round-bottom flask with 25 $\mathrm{mL}$ of deionized water. After stirring for $10 \mathrm{~min}$, the flask was placed in the center of an oil bath pot to be refluxed at $100{ }^{\circ} \mathrm{C}$ for $4 \mathrm{~h}$, followed by the injection of aqueous $\mathrm{Na}_{2} \mathrm{CO}_{3}$ solution ( $40 \mathrm{~mL}, 1 \mathrm{M}$ ) using a syringe pump at a rate of $1 \mathrm{~mL} \cdot \mathrm{min}^{-1}$, after which continued refluxing at $100{ }^{\circ} \mathrm{C}$ for $1 \mathrm{~h}$. Eventually, the product was collected by filtration and washed severally with deionized water. Finally, $\mathrm{FeOOH}, \mathrm{FeO}_{x}$, and $\alpha-\mathrm{Fe}_{2} \mathrm{O}_{3}$ were prepared by the calcination of the $\beta-\mathrm{FeOOH}$ precursor at 250, 400, and $500{ }^{\circ} \mathrm{C}$, respectively, for $4 \mathrm{~h}$ under Ar atmosphere.

\subsection{Catalyst preparation}

The iron oxide nanorods supported Au catalysts were prepared by a urea coprecipitation method. First, $300 \mathrm{mg}$ of iron oxide nanorods and $200 \mathrm{mg}$ of carbamide were dispersed in 25 $\mathrm{mL}$ of deionized water in a $100 \mathrm{~mL}$ round-bottom flask, followed by the addition of $2 \mathrm{~mL}$ of chloroauric acid $\left(\mathrm{HAuCl}_{4}, 3\right.$ $\mathrm{mg} \cdot \mathrm{mL}^{-1}$ ). The resulting solution was stirred for $30 \mathrm{~min}$ at room temperature. Afterward, the flask was placed in the center of an oil bath pot to be refluxed at $80^{\circ} \mathrm{C}$ for $5 \mathrm{~h}$. Eventually, the product was collected by filtration and washed severally with deionized water until it was free of $\mathrm{Cl}^{-}$. The final powders were dried at $60{ }^{\circ} \mathrm{C}$ in a vacuum oven overnight. The as-synthesized catalysts were denoted as $\mathrm{Au} / \mathrm{FeOOH}$-fresh, $\mathrm{Au} / \mathrm{FeO}_{x}$-fresh, and $\mathrm{Au} / \alpha-\mathrm{Fe}_{2} \mathrm{O}_{3}$-fresh; the fresh catalysts were further calcined at $200{ }^{\circ} \mathrm{C}$ under air flow $\left(100 \mathrm{~mL} \cdot \mathrm{min}^{-1}\right)$ and marked as $\mathrm{Au} / \mathrm{FeOOH}, \mathrm{Au} / \mathrm{FeO}_{x}$, and $\mathrm{Au} / \alpha-\mathrm{Fe}_{2} \mathrm{O}_{3}$, respectively.

\subsection{Catalyst characterization}

TEM and high-angle annular dark field scanning TEM (HAADF-STEM) images were acquired using an FEI Tecnai G2 F20 microscope equipped with a high-angle annular detector operating at $200 \mathrm{kV}$. The X-ray diffraction (XRD) patterns of the catalysts were obtained using an X-ray diffractometer (D/MAX-2400) with the $\mathrm{Cu} K_{\alpha}$ source at a scan rate of $2^{\circ} \cdot \mathrm{min}^{-1}$. $\mathrm{X}$-ray photoelectron spectroscopy (XPS) spectra were obtained using an Escalab 250Xi instrument with $\mathrm{Al} K_{\alpha}$ X-rays (1489.6 $\mathrm{eV}, 150 \mathrm{~W}, 50.0 \mathrm{eV}$ pass energies). The loading amounts of $\mathrm{Au}$ for the different catalysts were determined by Leeman Laboratories Prodigy inductively coupled plasma mass spectrometry (ICP-MS), and the experimental process is described as follows: A fraction $(10 \mathrm{mg})$ of each catalyst was dispersed in $5 \mathrm{~mL}$ of nitromurlatic acid with a $1: 3$ volume ratio of $\mathrm{HNO}_{3}: \mathrm{HCl}$. After the sample completely dissolved, the acid aqueous solution was diluted to $50 \mathrm{~mL}$ in a volumetric flask.

\subsection{Catalytic reaction}

The catalytic activity for the CO oxidation was performed using a continuous-flow fixed-bed reactor system. The $\mathrm{Au} / \mathrm{FeOOH}$ catalysts (containing $0.5 \mathrm{mg} \mathrm{Au}$ ) were used for the 
CO oxidation, while the amounts of the other catalysts were adjusted to maintain the same Au content according to the ICP results. The feed gas consisted of $1 \% \mathrm{CO}$ and $99 \%$ air or $1 \% \mathrm{CO}$ and $0.5 \% \mathrm{O}_{2}$ with a balance of He. (Total flow rate $=15$ $\mathrm{mL} \cdot \mathrm{min}^{-1}$; gas hourly space velocity (GHSV) $=1800$ $\left.\mathrm{mL} \cdot \mathrm{mg}^{-1} \cdot \mathrm{h}^{-1}\right)$. The reaction products were analyzed by GC (Agilent $7890 \mathrm{~A}$ ) equipped with a thermal conductivity detector (TCD).

\subsection{Stability of the catalysts investigated by the IL-TEM method}

IL-TEM was performed using a TEM grid with alphabetical or numerical codes. The TEM grid acts as a support, which allows the transfer of the catalyst between the electron microscope and gas-phase reaction environment [37]. In this study, before the reaction, small amounts of the catalysts were dissolved in ethanol and ultrasonicated for $10 \mathrm{~min}$ to obtain a homogeneous suspension. Very low amounts of the catalysts were deposited on a TEM copper grid with alphabetical codes, followed by drying under infrared light. Subsequently, the grid with the samples was inserted into TEM to capture the initial states of the catalysts. Afterward, the TEM grid was transferred to a gas phase reactor, where the catalysts participated in the CO oxidation reaction. Finally, the TEM grid was taken out after the reaction and transferred to the electron microscope once more to acquire the TEM images at identical locations. The accurate locations of the catalyst were tracked using the alphabetical codes on the TEM grid. The entire process was performed without modifying the structure of the TEM device.

\section{Results and discussion}

\subsection{Preparation and characterization of the iron oxide nanorods support}

$\mathrm{FeOOH}, \mathrm{FeO}_{x}, \alpha-\mathrm{Fe}_{2} \mathrm{O}_{3}$ were prepared by the calcination of the $\beta$-FeOOH precursor at 250,400 , and $500{ }^{\circ} \mathrm{C}$, respectively, for $4 \mathrm{~h}$, under Ar atmosphere, and were further used as supports for Au NPs. The powder XRD patterns (Fig. S1(a)) confirm the $\mathrm{FeOOH}$ and $\alpha-\mathrm{Fe}_{2} \mathrm{O}_{3}$ phase structures for $\beta$-FeOOH treated at 250 and $500{ }^{\circ} \mathrm{C}$, according to JCPDS 18-0639 and JCPDS 79-0009, respectively. $\mathrm{FeO}_{x}$, obtained after calcination at 400
${ }^{\circ} \mathrm{C}$, exhibits a transient structure between those of $\mathrm{FeOOH}$ and $\alpha-\mathrm{Fe}_{2} \mathrm{O}_{3}$. The support structures are further confirmed by corresponding Raman spectra, as shown in Fig. S1(b). Along with the increase in the calcination temperature, the specific surface area of the material exhibits an evident decrease from 105.1 via 65.6 to $53 \mathrm{~m}^{2} \cdot \mathrm{g}^{-1}$, and the corresponding pore diameter exhibits a concomitant increase from 3.5 via 7.1 to $11.7 \mathrm{~nm}$, as displayed in the nitrogen adsorption-desorption isotherms in Fig. S1(c) and Table S1. The low-magnification HAADF-STEM and TEM images in Figure S2 indicate regular nanorods structure for all the synthesized supports. Furthermore, it can be easily observed that a gradually enlarged pore structure can be obtained with the elevated calcination temperature for the iron oxides.

\subsection{Synthesis and characterization of the catalysts}

Fresh $\mathrm{Au}$ /iron oxide series of catalysts were obtained by a urea coprecipitation process, and the catalysts were named $\mathrm{Au} / \mathrm{FeOOH}$-fresh, $\mathrm{Au} / \mathrm{FeO}_{x}$-fresh, and $\mathrm{Au} / \alpha-\mathrm{Fe}_{2} \mathrm{O}_{3}$-fresh. The as-prepared fresh catalysts, after undergoing further calcination at $200{ }^{\circ} \mathrm{C}$ for $2 \mathrm{~h}$, under pure airflow, were designated as $\mathrm{Au} / \mathrm{FeOOH}, \mathrm{Au} / \mathrm{FeO}_{x}$, and $\mathrm{Au} / \alpha-\mathrm{Fe}_{2} \mathrm{O}_{3}$, respectively. The ICP results listed in Table $\mathrm{S} 2$ show that the loading amounts of $\mathrm{Au}$ for the $\mathrm{Au} / \mathrm{FeOOH}, \mathrm{Au} / \mathrm{FeO}_{x}$ and $\mathrm{Au} / \alpha-\mathrm{Fe}_{2} \mathrm{O}_{3}$ catalysts are 1.9, 2.1, and $2.4 \mathrm{wt} \%$, respectively. The XRD patterns of the fresh and activated $\mathrm{Au}$-based catalysts after calcination, are exhibited in Fig. 1(a) and 1(b). All the catalysts display strong peaks, which are indicative of the support structures. No obvious peak assignable to the Au NPs is found in the fresh catalysts (Fig. 1(a)), indicating the significantly small sizes of the Au NPs. In addition, low-magnification HAADF-STEM together with corresponding particle size distributions (PSDs) and TEM images in Figure S3 verify the ultra-small-sized Au clusters in the fresh catalysts; the mean particle sizes are measured to be $0.7 \pm 0.2$, $1.0 \pm 0.3$, and $0.9 \pm 0.2 \mathrm{~nm}$ for $\mathrm{Au} / \mathrm{FeOOH}$-fresh, $\mathrm{Au} / \mathrm{FeO}_{x}$-fresh, and $\mathrm{Au} / \alpha-\mathrm{Fe}_{2} \mathrm{O}_{3}$-fresh samples, respectively. The energy dispersive X-ray spectroscopy (EDX) elemental maps of these fresh catalysts in Fig. S4 also exhibit the well-distributed O, Fe, and $\mathrm{Au}$ elements in each sample. After calcination under air, at $200{ }^{\circ} \mathrm{C}$, a small peak at $38.2^{\circ}$ ascribed to the $\mathrm{Au}(111)$ plane (JCPDS 04-0784) appears on the FeOOH support; this peak is
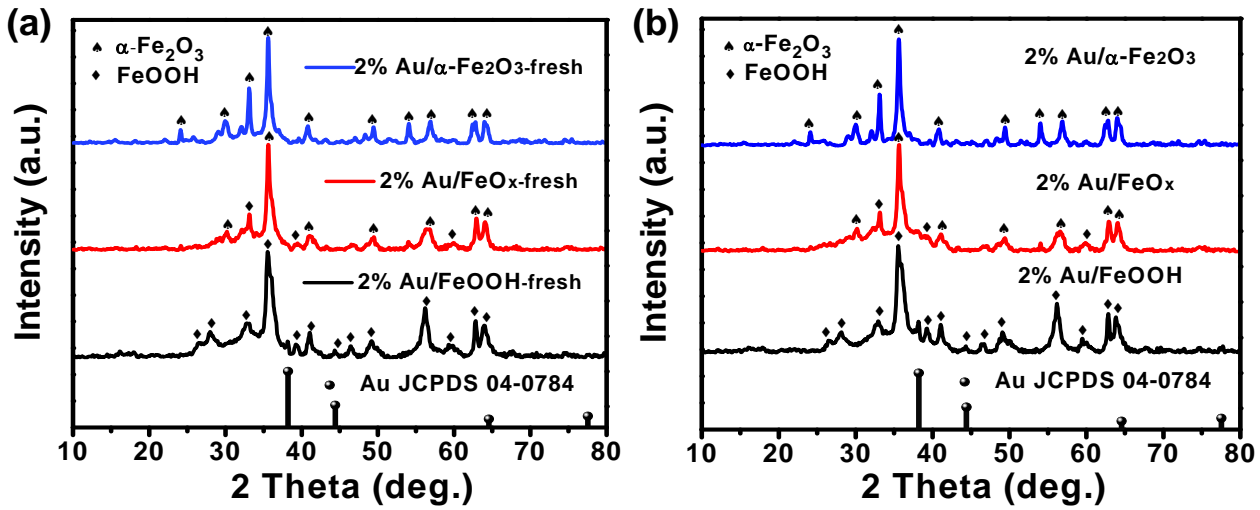

Fig. 1. XRD patterns of the as-prepared $\mathrm{Au} / \mathrm{FeOOH}, \mathrm{Au} / \mathrm{FeO}$, and $\mathrm{Au} / \mathrm{a}-\mathrm{Fe}_{2} \mathrm{O}_{3}$ catalysts before (a) and after (b) calcination. 
observed to be weaker on the $\mathrm{FeO}_{x}$ and $\alpha-\mathrm{Fe}_{2} \mathrm{O}_{3}$ supports (Fig. 1(b)). The representative low-magnification HAADF-STEM images and corresponding EDX elemental maps of the three activated $\mathrm{Au}$ /iron oxide catalysts are further shown in Fig. 2(a)-(c) and Fig. S5. Statistical analyses of the PSDs were carried out by measuring ca. $400 \mathrm{Au}$ NPs in corresponding HAADF-STEM images for each sample, and the mean diameters of $\mathrm{Au}$ NPs are estimated to be $2.5 \pm 0.5,3.9 \pm 0.8$, and $3.5 \pm 0.7$ $n m$ regarding $\mathrm{Au} / \mathrm{FeOOH}, \mathrm{Au} / \mathrm{FeO}_{x}$, and $\mathrm{Au} / \alpha-\mathrm{Fe}_{2} \mathrm{O}_{3}$ catalysts, respectively. The size of supported Au NPs exhibits a close relationship with the surface properties of different iron oxides, and the supported Au NPs is more likely to be positioned on the pore edges of the iron oxide surface, particularly for the $\mathrm{Au} / \mathrm{FeO}_{x}$ catalyst with medium pore sizes. For the $\mathrm{Au}$ NPs with the smallest sizes, high dispersion on the $\mathrm{FeOOH}$ support is clearly observed. The crystal structures of the supported $\mathrm{Au}$ NPs for the calcined catalysts were revealed by high-resolution TEM (HRTEM) images with local fast Fourier transforms (FFTs), as shown in Fig. 2(d)-(f). The measured lattice spacings of 0.236 and $0.204 \mathrm{~nm}$, obtained by forming an angle of $54.78^{\circ}$ for the $\mathrm{Au}$ nanocrystals from HRTEM images of $\mathrm{Au} / \mathrm{FeOOH}$ catalyst, correspond to the (111) and (200) crystal planes of the face-centered cubic (FCC) phase of Au. In addition, sharp bright diffraction spots are shown in FFTs, illustrating the high crystallinity of the small-sized Au NPs. Therefore, the appearance of a $\mathrm{Au}$ peak in the XRD pattern for the calcined $\mathrm{Au} / \mathrm{FeOOH}$ sample is not only owing to the increased particle size, but also mainly to the good crystallization of the supported $\mathrm{Au}$ NPs. However, the $\mathrm{Au}$ NPs supported on $\mathrm{FeO}_{x}$ and $\alpha-\mathrm{Fe}_{2} \mathrm{O}_{3}$, as multiple twinning structures, are shown in Fig. 2(e) and (f) due to the particle growth during the thermal treatment, which is consistent with the weak peak of Au observed in the XRD patterns. It is widely reported that Au NPs with large sizes always adopt the multi-twinned structure by reducing their surface energies [38,39].

To study the surface properties of the supports and the chemical states of $\mathrm{Au}$ for the $\mathrm{Au} /$ iron oxide series catalysts, XPS analysis was carried out and the results are summarized in Fig. 3. The Au $4 f$ XPS spectra for the fresh samples were analyzed, as shown in Fig. 3(a). The Au $4 f$ spectra can be deconvoluted into two couples of speaks due to the spin-orbit split doublet of $\mathrm{Au} 4 f_{7 / 2}$ and $4 f_{5 / 2}$, which represent two kinds of Au species, with binding energies (BE) of about 86.7 and $90.2 \mathrm{eV}$ for $\mathrm{Au}^{1+}$, and 87.4 and $90.9 \mathrm{eV}$ for $\mathrm{Au}^{3+}[40,41]$. Most of the Au NPs are in the form of $\mathrm{Au}^{3+}$ in the fresh samples and there is no obvious difference among them before calcination. While the $01 s$ spectra for the as-prepared fresh samples (Fig. 3(b)) show a clear difference after division into four components. According to previous reports, the $\mathrm{BE}$ of oxygen at 529.5, 530.1, 531.6, and $533.2 \mathrm{eV}$ for the fresh catalysts can be ascribed to the surface oxygen, the surface hydroxyl $(-\mathrm{OH})$, lattice oxygen, and chemisorbed water, respectively [42]. Along with the increased preparation temperatures of the supports, the surface hydroxyl component exhibits an evident decrease from $\mathrm{FeOOH}$ to $\alpha-\mathrm{Fe}_{2} \mathrm{O}_{3}$. For the catalysts after calcination, two main peaks at the $\mathrm{BE}$ of 83.4 and $83.8 \mathrm{eV}$ assigned to the $4 f_{7 / 2}$ of $\mathrm{Au}^{0}$ and slightly positive charged $\mathrm{Au}^{\delta+}(0<\delta<1)$, respectively, were identified for the $\mathrm{Au} / \mathrm{FeOOH}, \mathrm{Au} / \mathrm{FeO}_{x}$, and $\mathrm{Au} / \alpha-\mathrm{Fe}_{2} \mathrm{O}_{3}$ catalysts in Fig. 3(c) $[43,44]$. Notably, the Au $4 f$ spectra of different $\mathrm{Au} /$ iron oxide catalysts present apparent distinctions. The shift of the $\mathrm{BE}$ of $\mathrm{Au} 4 f_{7 / 2}$ in the $\mathrm{Au} / \mathrm{FeOOH}$ sample toward the low-energy side, can be clearly observed, implying that the $\mathrm{Au}$ NPs supported on $\mathrm{FeOOH}$ tend to have more $\mathrm{Au}^{0}$ species than the other two catalysts do, which is consistent with the deconvoluted results, as highlighted in the pink-filled area in Fig. 3(c). Besides, the surface hydroxyl species are absent on the surfaces
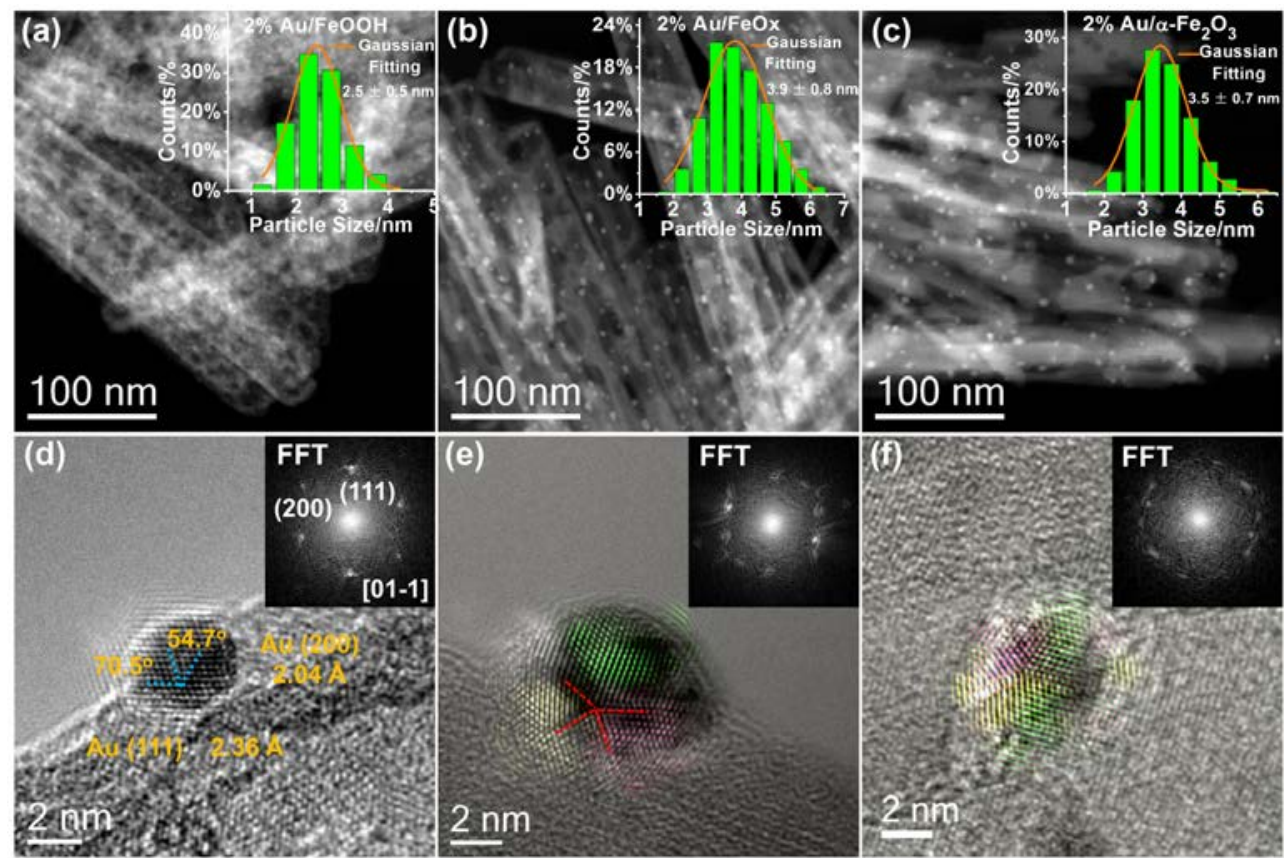

Fig. 2. STEM and HRTEM images of the calcined $\mathrm{Au} / \mathrm{FeOOH}(\mathrm{a}, \mathrm{d}), \mathrm{Au} / \mathrm{Fe} \mathrm{O}_{x}(\mathrm{~b}, \mathrm{e})$, and $\mathrm{Au} / \mathrm{a}-\mathrm{Fe}_{2} \mathrm{O}_{3}(\mathrm{c}, \mathrm{f})$ catalysts. The insets are the corresponding PSD histograms (a-c) and local fast Fourier transforms (d-f) (FFTs). 

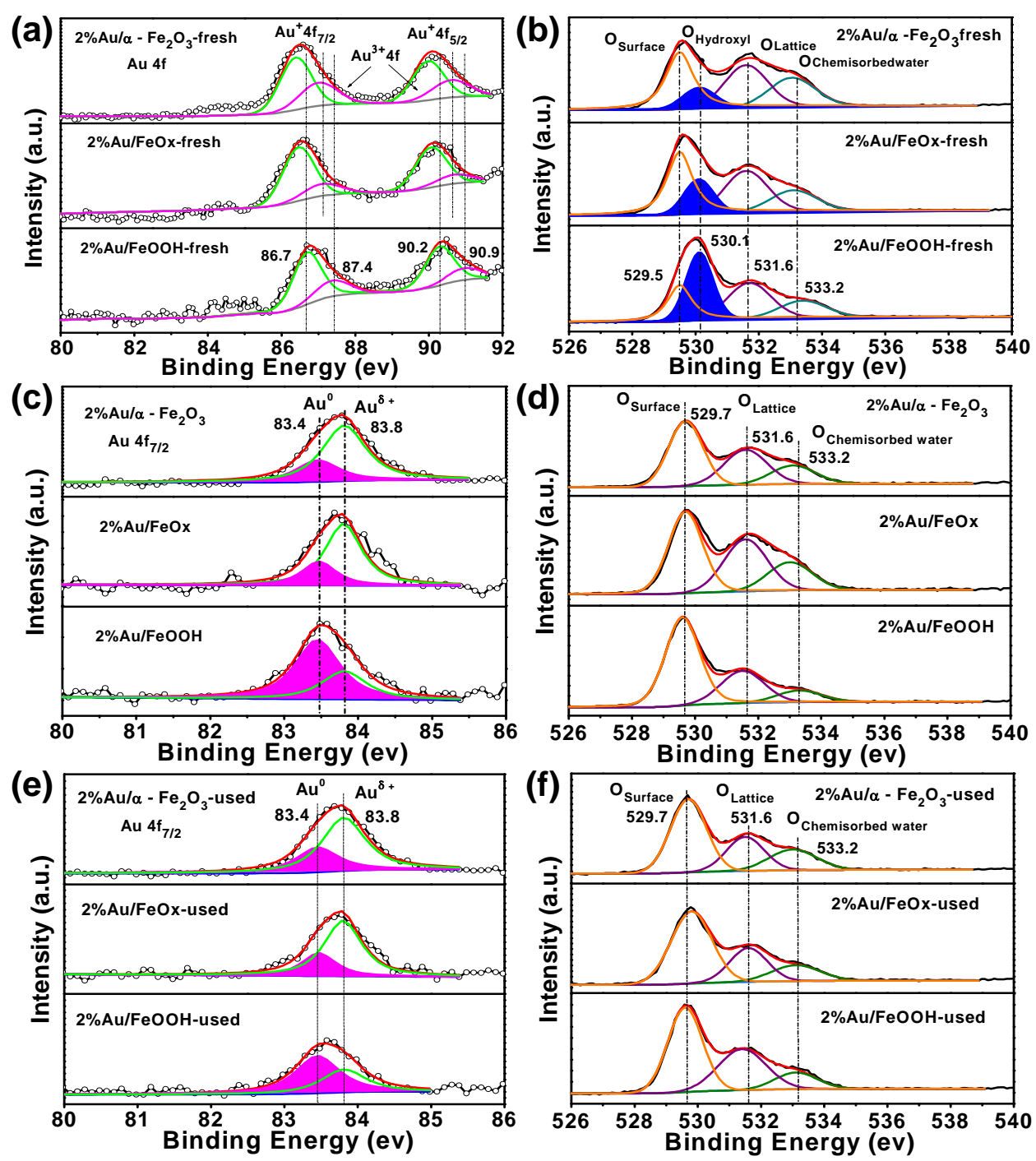

Fig. 3. XPS analyses of the $\mathrm{Au} / \mathrm{FeOOH}, \mathrm{Au} / \mathrm{FeO}_{x}$, and $\mathrm{Au} / \mathrm{a}-\mathrm{Fe}_{2} \mathrm{O}_{3}$ catalysts before $(\mathrm{a}, \mathrm{b})$, and after (c,d) calcination, and after application (e,f) in $\mathrm{CO}$ oxidation.

of the activated catalysts, as displayed in Fig. 3(d). In this study, the $\mathrm{FeOOH}$ support with the most surface $-\mathrm{OH}$ groups before the calcination possesses had the highest $\mathrm{Au}^{0}$ content after thermal treatment, strongly demonstrating that the surface hydroxyl groups on the iron oxide supports are crucial in the formation of $\mathrm{Au}^{0}$ species [45].

\subsection{CO oxidation activity and temporal stability}

The conversion of $\mathrm{CO}$ as a function of the reaction temperature for the fresh and activated Au-based catalysts is shown in Fig. 4(a) and (b). $\mathrm{Au} / \mathrm{FeOOH}$-fresh exhibits low-temperature $\mathrm{CO}$ oxidation reactivity at $25{ }^{\circ} \mathrm{C}$ (CO conversion 5.8\%), and the conversion reaches $100 \%$ when the temperature is elevated to $110{ }^{\circ} \mathrm{C}$. Conversely, the $\mathrm{Au} / \mathrm{FeO}_{x}$-fresh and $\mathrm{Au} / \alpha-\mathrm{Fe}_{2} \mathrm{O}_{3}$-fresh catalysts display no reactivity at room temperature. Reportedly, the surface $-\mathrm{OH}$ species on the transition metal oxides can readily react with the $\mathrm{CO}$ adsorbed nearby to directly yield $\mathrm{CO}_{2}$ and simultaneously produce coordinatively unsaturated sites for $\mathrm{O}_{2}$ activation, offering the $\mathrm{Pt}$ or $\mathrm{Au}$ based catalysts with low-temperature reactivity in CO oxidation [46-48]. From the characterizations and analyses performed in this study, the low-temperature reactivity of the $\mathrm{Au} / \mathrm{FeOOH}$-fresh catalyst may be attributed to the abundant $-\mathrm{OH}$ species on the $\mathrm{FeOOH}$ support surface, which can assist the Au cation with oxygen adsorption and dissociation. To determine the stability of the $\mathrm{Au} / \mathrm{FeOOH}$-fresh catalyst, a long time-on-stream experiment was performed at $45^{\circ} \mathrm{C}$ for $12 \mathrm{~h}$. As can be observed in Fig. 4(c), the $\mathrm{Au} / \mathrm{FeOOH}$-fresh catalyst exhibits gradually decreased activity, indicating the poor stabilities of the surface $-\mathrm{OH}$ groups under the reaction condition. Furthermore, the $\mathrm{Au} / \mathrm{FeOOH}$-fresh catalyst after a durability test by TEM (Fig. S6), displayed the growth of Au NPs due to the reduced surface -OH anchoring sites. The catalytic performances of the activated Au-based catalysts in $\mathrm{CO}$ oxidation are shown in Fig. 4(b). The conversion of $\mathrm{CO}$ on the $\mathrm{Au} / \mathrm{FeOOH}$ catalyst was readily $36.8 \%$ at $25{ }^{\circ} \mathrm{C}$ and approached $100 \%$ at $80{ }^{\circ} \mathrm{C}$. For the $\mathrm{Au} / \mathrm{FeO}_{x}$ catalyst, the conversion of $\mathrm{CO}$ was only $9.1 \%$ at $25{ }^{\circ} \mathrm{C}$, and the 

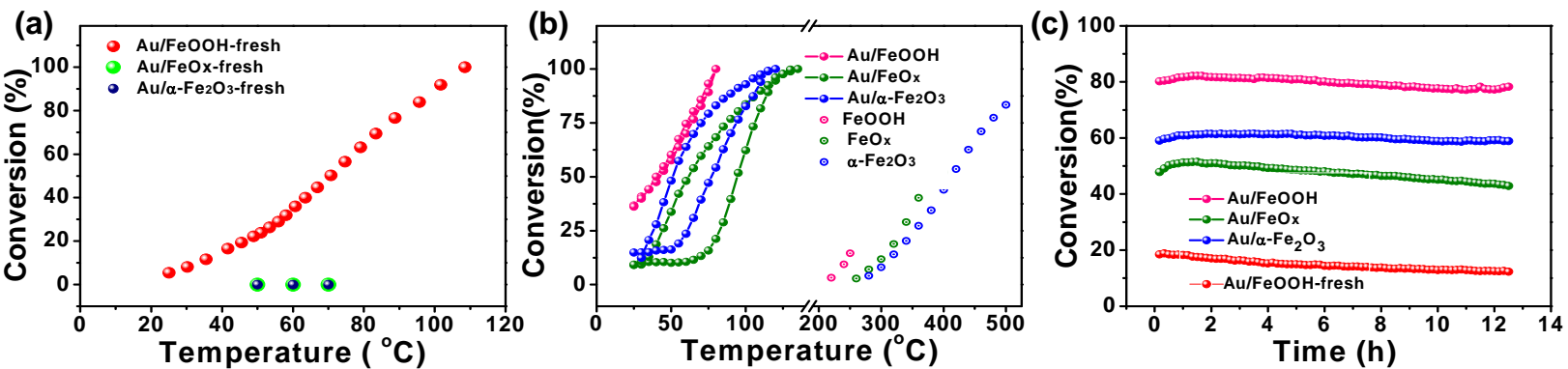

Fig. 4. $\mathrm{CO}$ conversion curves with reaction temperatures over the $\mathrm{Au} / \mathrm{FeOOH}, \mathrm{Au} / \mathrm{FeO}_{x}$, and $\mathrm{Au} / \mathrm{a}-\mathrm{Fe}_{2} \mathrm{O}_{3}$ catalysts before (a) and after (b) calcination. (c) The durability tests of the as-synthesized catalysts at $60^{\circ} \mathrm{C}$ for $12 \mathrm{~h}$. Reaction gas composition: $1.0 \mathrm{v} \% \mathrm{CO}, 99 \mathrm{v} \%$ air; GHSV $=1800 \mathrm{~mL} \cdot \mathrm{mg}^{-1} \cdot \mathrm{h}^{-1}$.

full conversion of $\mathrm{CO}$ was achieved until $125{ }^{\circ} \mathrm{C}$. For the $\mathrm{Au} / \alpha-\mathrm{Fe}_{2} \mathrm{O}_{3}$ sample, a $14.9 \%$ conversion of $\mathrm{CO}$ was obtained at $25{ }^{\circ} \mathrm{C}$ and $100 \%$ conversion of $\mathrm{CO}$ occurred at $115^{\circ} \mathrm{C}$. The results clearly demonstrate that $\mathrm{Au} / \mathrm{FeOOH}$ exhibits the highest reactivity among the as-synthesized catalysts after calcination under air at $200{ }^{\circ} \mathrm{C}$. In addition, the $\mathrm{Au} / \mathrm{FeO}_{x}$ and $\mathrm{Au} / \mathrm{Fe}_{2} \mathrm{O}_{3}$ catalysts exhibit an obvious increase in catalytic performances during the programmed cooling process. The stabilities of the activated Au-based catalysts were evaluated in the CO oxidation reaction for $12 \mathrm{~h}$ after the programmed heating and cooling procedure. No obvious degradation was observed for the $\mathrm{Au} / \mathrm{FeOOH}$ and $\mathrm{Au} / \alpha-\mathrm{Fe}_{2} \mathrm{O}_{3}$ catalysts, as shown in Fig. 4(c). However, the activity of the $\mathrm{Au} / \mathrm{FeO}_{x}$ sample decreased gradually as the reaction proceeded, from $51 \%$ to $42 \%$ after $12 \mathrm{~h}$. The above results unambiguously show that the $\mathrm{Au} / \mathrm{FeOOH}$ catalyst is not only highly active but also extremely stable in CO oxidation after calcination. As discussed previously, the Au NPs on $\mathrm{FeOOH}$ after thermal treatment are highly dispersed as $\mathrm{Au}^{0}$ with a small mean particle size of $2.5 \mathrm{~nm}$, which greatly con- tributes to the high catalytic activity in the $\mathrm{CO}$ oxidation. Conversely, the wide PSDs with a large mean Au NP size and low $\mathrm{Au}^{0}$ content for the $\mathrm{Au} / \mathrm{FeO}_{x}$ and $\mathrm{Au} / \alpha-\mathrm{Fe}_{2} \mathrm{O}_{3}$ samples can, in principle, provide a reasonable explanation for the much relatively low activity.

The XRD patterns of the calcined Au/iron oxide catalysts after usage and durability tests in CO oxidation are shown in Fig. S7. Characteristic peaks similar to those before the reaction, are observed. In addition, XPS analysis of Au $4 f$ and $01 s$ spectra for the used catalysts are shown in Fig. 3(e) and (f), illustrating the barely changed chemical states of Au NPs. The HAADF-STEM images of the samples after usage and durability tests are exhibited in Figs. 5(a)-(c) and S8. The statistical analyses of the PSDs are shown in the corresponding HAADF-STEM images, and the mean diameters of the Au NPs are $2.3 \pm 0.5,3.6 \pm 0.8$, and $3.0 \pm 0.7 \mathrm{~nm}$, regarding the used $\mathrm{Au} / \mathrm{FeOOH}, \mathrm{Au} / \mathrm{FeO}_{x}$ and $\mathrm{Au} / \alpha-\mathrm{Fe}_{2} \mathrm{O}_{3}$ catalysts, respectively, and $2.1 \pm 0.6,3.5 \pm 0.8$, and $3.2 \pm 0.7 \mathrm{~nm}$ for the cycled ones. Negligible changes in the $\mathrm{Au}$ NPs sizes for the $\mathrm{Au} / \mathrm{FeOOH}$ catalysts were observed, while a
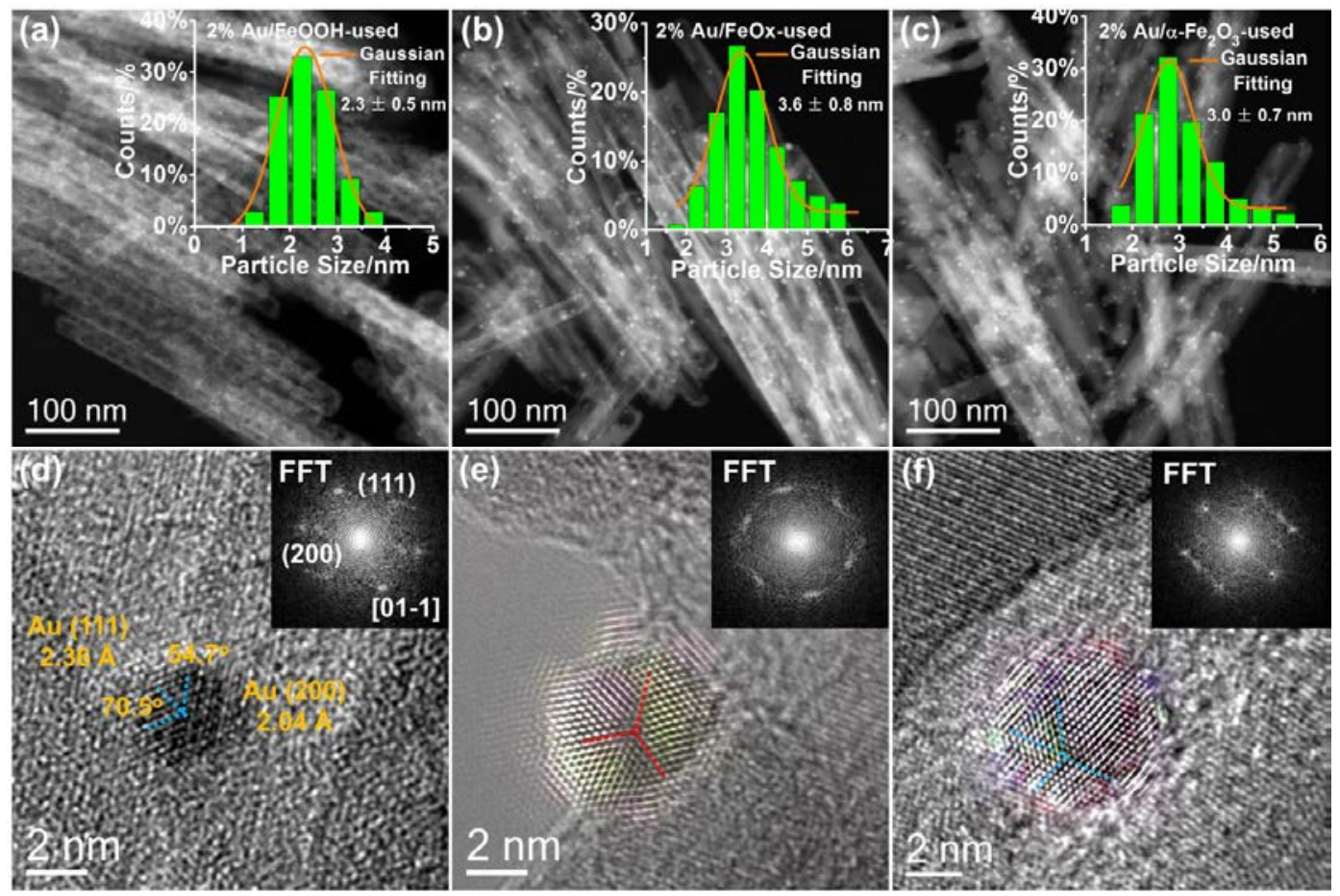

Fig. 5. STEM and HRTEM images of the calcined $\mathrm{Au} / \mathrm{FeOOH}(\mathrm{a}, \mathrm{d}), \mathrm{Au} / \mathrm{FeO} \mathrm{O}_{x}(\mathrm{~b}, \mathrm{e})$, and $\mathrm{Au} / \mathrm{a}-\mathrm{Fe}_{2} \mathrm{O}_{3}(\mathrm{c}, \mathrm{f})$ catalysts after application in $\mathrm{CO}$ oxidation. The insets are the corresponding PSD histograms $(\mathrm{a}-\mathrm{c})$ and FFTs $(\mathrm{d}-\mathrm{f})$. 
slightly reduced mean Au NP size together with an increase in the number of small-sized $\mathrm{Au}$ is found for the used $\mathrm{Au} / \mathrm{FeO}_{x}$ and $\mathrm{Au} / \alpha-\mathrm{Fe}_{2} \mathrm{O}_{3}$ catalysts, which exemplifies the increased catalytic performance for the prepared catalysts during the cooling process. Besides, with the increase in the amount of small-sized $\mathrm{Au}$ for the cycled catalysts, some large Au NPs also appear on the $\mathrm{FeO}_{x}$ support, which can be observed from the tail of the corresponding PSD after a long reaction time (Fig. S8). HRTEM images for the used and cycled samples demonstrate a well-crystallized $\mathrm{Au}$ on $\mathrm{FeOOH}$, and seldom-changed multiple twinning structures on $\mathrm{FeO}_{x}$ and $\alpha-\mathrm{Fe}_{2} \mathrm{O}_{3}$. All the results obtained here strongly suggest a support-dependent structure evolution of $\mathrm{Au}$ particles on varied iron oxides during the $\mathrm{CO}$ oxidation.

\subsection{Stability of the catalysts studied by IL-TEM method}

Traditionally, the investigation on the structure evolution of nanocatalysts is always achieved by the comparison of TEM analyses results between the fresh and used samples. The conclusions drawn from different areas of the sample are useful, but not always accurate and intuitive. Moreover, it is hard to distinguish whether the structural changes originated from the synthesis procedure or the reaction process; more so, some detailed information was not easily noticeable. An advanced IL-TEM technique can well complement the standard microscopic study, thereby providing a simple method to track the catalyst at the same location during the reaction. Moreover, the technique offers a new insight into the structure evolution of the catalytic materials [49-51].

The stability of the Au NPs dispersed on iron oxide support is important for their extensive use as efficient catalysts in CO oxidation. To further explore the relationship between the $\mathrm{Au}$ NPs behavior and the stabilities of the catalysts, a gas-phase reaction in an IL-TEM reactor designed by our group, as shown in Fig. 7(a), is used to accurately record the structure evolution of identical locations of the Au-oxides series catalysts at different reaction stages during the $\mathrm{CO}$ oxidation. The low-magnification HAADF-STEM and HRTEM images of the $\mathrm{Au} / \mathrm{FeOOH}$ and $\mathrm{Au} / \mathrm{FeO}_{x}, \mathrm{Au} / \alpha-\mathrm{Fe}_{2} \mathrm{O}_{3}$ catalysts at identical locations before and after application and after durability tests in CO oxidation, are shown in Fig. 6 and Figs. S9-12. Statistical
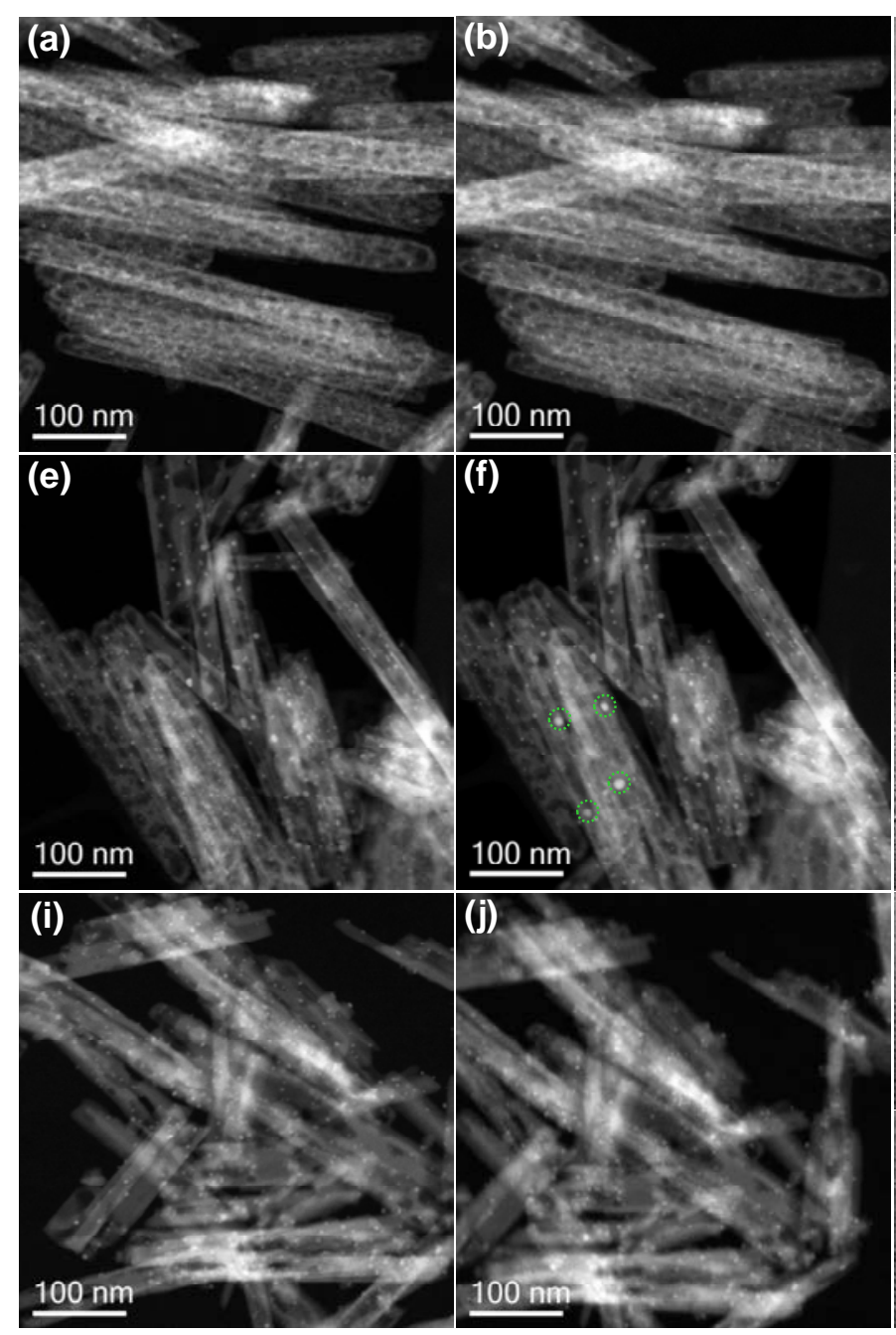
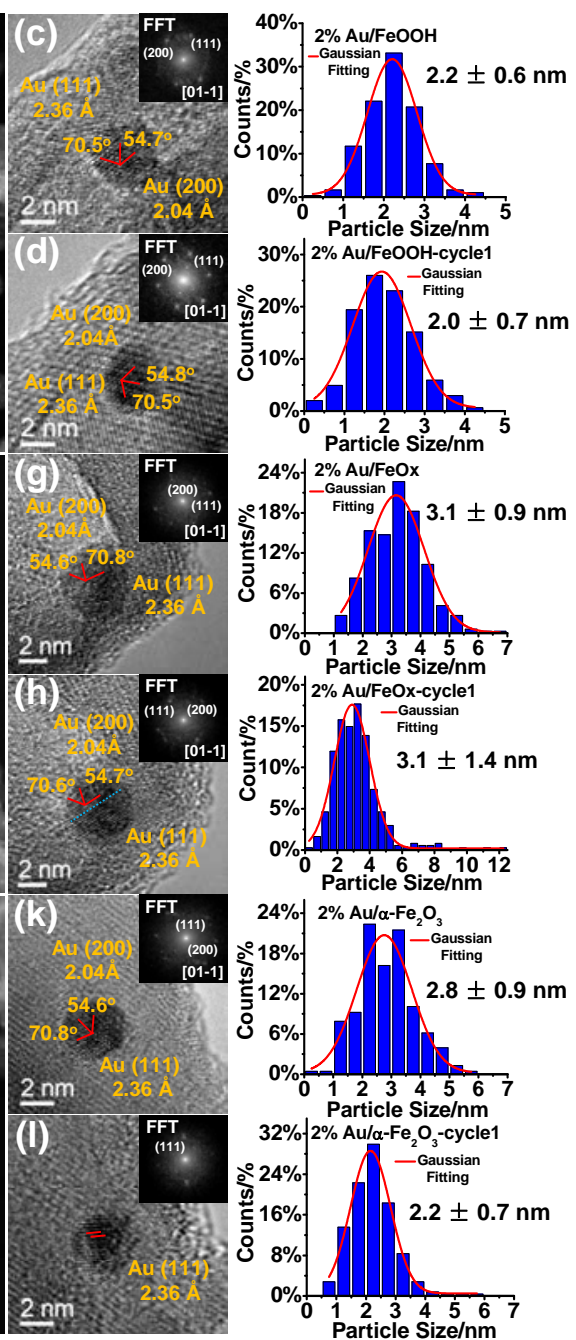

Fig. 6. Identical location STEM and HRTEM images of the calcined $\mathrm{Au} / \mathrm{FeOOH}(\mathrm{a}-\mathrm{d}), \mathrm{Au} / \mathrm{FeO}_{x}\left(\mathrm{e}-\mathrm{h}\right.$ ), and $\mathrm{Au} / \mathrm{a}-\mathrm{Fe} \mathrm{O}_{3}(\mathrm{i}-\mathrm{l}) \mathrm{catalysts,}$ before and after $10 \mathrm{~h}$ durability tests. The corresponding PSD histograms were constructed by quantifying a series of identical location STEM images. Reaction gas composition: $1.0 \mathrm{v} \% \mathrm{CO}$ and $99 \mathrm{v} \%$ air, balanced with He. 

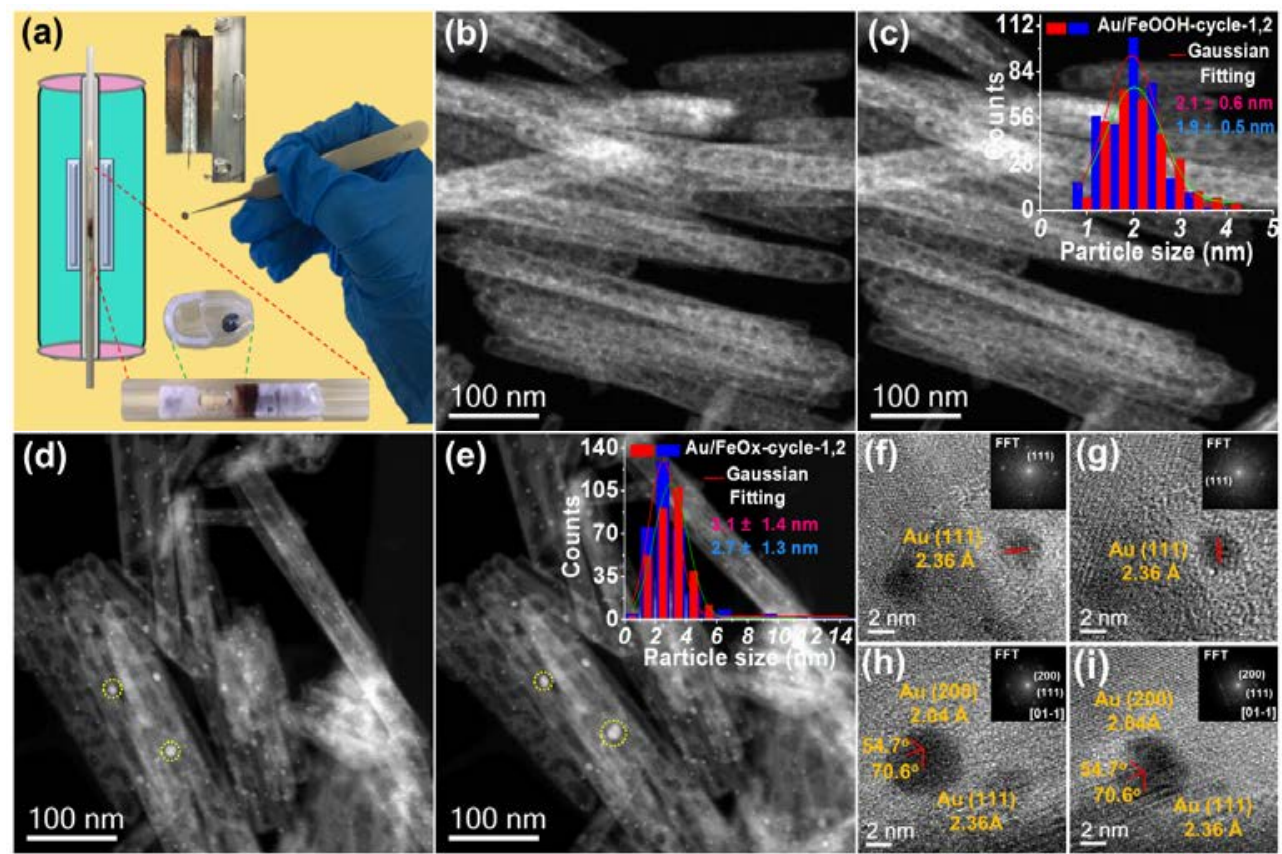

Fig. 7. (a) Schematic of the IL-TEM gas-phase reactor, STEM and HRTEM images of the Au/FeOOH calcined (b-c, and f-g) and Au/FeO $(\mathrm{d}-\mathrm{e}$, and h-i) catalysts after different durability tests in $\mathrm{CO}$ oxidation reaction for $10 \mathrm{~h}$. Reaction gas composition: $1.0 \mathrm{v} \% \mathrm{CO}$ and $99 \mathrm{v} \%$ air, balanced with He for cycle- 1 (b, d, f, h) and $1.0 \mathrm{v} \% \mathrm{CO}$ and $0.5 \mathrm{v} \% \mathrm{O}_{2}$, balanced with He for cycle-2 (c, e, h, i).

analyses of an ensemble of $\mathrm{Au} \mathrm{NPs}$ on $\mathrm{FeOOH}$ and $\alpha-\mathrm{Fe}_{2} \mathrm{O}_{3}$ showed that the particles exhibit only a slight decrease from $2.2 \pm 0.6$ to $2.0 \pm 0.7$ and $2.8 \pm 0.9$ to $2.2 \pm 0.7 \mathrm{~nm}$, respectively, and that the proper dispersion is maintained after a long time-on-stream reaction. Whereas a notably different phenomenon is observed on the $\mathrm{Au} / \mathrm{FeO}_{x}$ catalyst, some irregular relatively large particles with sizes more than $8 \mathrm{~nm}$, highlighted with green circles, appeared on the $\mathrm{FeO}_{x}$ support. In addition, the PSD shape changes from an initial Gaussian distribution to a log-normal distribution with a tail in the PSD towards relatively large sizes after $10 \mathrm{~h}$ durability tests, as shown in Fig. 6 (g) and (h) [52,53].

To further analyze the detailed behavior of the Au NPs, consecutive HRTEM images for the as-prepared catalysts were recorded at different reaction stages. From the HRTEM images of all the samples, it can be observed that the Au NPs with high-index rough surfaces adopt more flat facets, accompanied by a little reduced particle size after a long CO oxidation time, which is in accordance with the increased amount of small $\mathrm{Au}$ particles in the range of 1-2 nm determined by comparing the PSDs statistics in Fig. 6. According to previous research and the result from the experiment, it can be deduced that the mobility of the surface Au atom may increase through the chemical adsorption interaction with reactants under a working condition; therefore, the Au species can migrate along with the gas flow [54-56]. To clarify further the dominant factor for this phenomena, the gas composition was changed from a mixture of $1 \% \mathrm{CO}$ with $99 \%$ air to $1 \% \mathrm{CO}$ and $0.5 \% \mathrm{O}_{2}$, with a balance of $\mathrm{He}$, by reducing the $\mathrm{O}_{2}$ content. The results are shown in Figs. 7 and S12. The continued growth of the large $\mathrm{Au}$ particles marked with yellow circles is clearly observed on the $\mathrm{Au} / \mathrm{FeO}_{x}$ catalyst and the number of small $\mathrm{Au}$ particles within
1-2 nm increased both for the $\mathrm{Au} / \mathrm{FeO}_{x}$ and $\mathrm{Au} / \mathrm{FeOOH}$ catalysts. Based on the evidence obtained, the hypothesis, that the behavior of Au NPs mediated by a process similar to Ostwald ripening on $\mathrm{Au}$ /iron oxide catalysts, probably owing to the interaction between $\mathrm{Au}$ and the CO component, is established. The large particles grow at the expense of small ones in the $\mathrm{Au} / \mathrm{FeO}_{x}$ catalyst, possibly owing to the interparticle transport of the $\mathrm{Au}(\mathrm{CO})_{x}$ mobile species. The formation of large Au particles on the $\mathrm{FeO}_{x}$ support indicated the decline in the active surface area for the CO oxidation, which is consistent with the gradually lowered activity observed in the durability test. Furthermore, the different behavior of supported Au NPs on varied iron oxides may be due to the diffusion length limitation of $\mathrm{Au}(\mathrm{CO})_{x}$ species which is caused by the pore structures on the support surfaces. The edges of the pore show unsaturated coordination points, which can act as anchor sites to capture $\mathrm{Au}(\mathrm{CO})_{x}$ species and redisperse the $\mathrm{Au} \mathrm{NPs}$; $\mathrm{FeO}_{x}$ with a medium pore size shows a stronger trapping capacity than $\alpha-\mathrm{Fe}_{2} \mathrm{O}_{3}$, which has a large pore, does. Therefore, through quantifying a series of identical location STEM at low magnification and HRTEM images of the individual NPs, the sophisticated behavior of Au NPs on iron oxides with different structures can be speculated to some degree and the relationship between the active site structure and catalytic performance can be well understood.

Herein, the gas phase IL-TEM method offers an intuitive insight into the delicate structure evolution of the catalysts, which provides a new approach to accurately studying the structure-performance relationship in some gas phase reactions. Most importantly, the nondestructive gas phase IL-TEM can be well extended to some electron beam sensitive materials or can deal with some unfavorable reaction conditions, e.g., 
some corrosive gases, which are difficult to operate under environment TEM or harmful to the in situ holder device, to uncover the real active site generated under the reaction condition or the reason for deactivation of the reaction.

\section{Conclusions}

$\mathrm{Au}$ NPs supported on iron oxide nanorods with different surface properties were synthesized by a urea coprecipitation process. For the catalysts before calcination, the ultra-small-sized $\mathrm{Au}$ NPs exist on iron oxides with varied surface properties and mainly adopt the form of $\mathrm{Au}^{3+}$. The surface hydroxyl species on the $\mathrm{FeOOH}$ support is considered the main reason for the $\mathrm{Au} / \mathrm{FeOOH}$-fresh catalysts exhibiting reactivity at room temperature compared to the cases of the $\mathrm{Au} / \mathrm{FeO}_{x}$-fresh and $\mathrm{Au} / \alpha-\mathrm{Fe}_{2} \mathrm{O}_{3}$-fresh catalysts. For the activated catalyst, the positively charged Au species on different iron oxides partly change to $\mathrm{Au}^{0}$ along with the disappearance of the surface $-\mathrm{OH}$ species for the support materials. $\mathrm{Au} / \mathrm{FeOOH}$ with the highest $\mathrm{Au}^{0}$ content and smallest particle size exhibits the highest catalytic activity among the as-synthesized catalysts. Besides, no obvious decrease in the activity of the $\mathrm{Au}-\mathrm{FeOOH}$ catalyst was observed in the CO oxidation within 12 h. Furthermore, a gas phase IL-TEM method was adopted to explore the delicate structure evolution of the series of catalysts. The results indicate that the behavior of the Au NPs depends on both the support structure and the size of the supported NPs. For the $\mathrm{Au}$ NPs supported on $\mathrm{FeOOH}$ and $\alpha-\mathrm{Fe}_{2} \mathrm{O}_{3}$, an increase in the amounts of small particles in the range of $1-2 \mathrm{~nm}$ is shown after a long CO oxidation reaction time. Conversely, with the increased amount of small particles, some irregularly large Au particles with sizes more than $8 \mathrm{~nm}$ appear simultaneously on the $\mathrm{FeO}_{x}$ support after the long reaction. The behavior of the Au NPs mediated by a process similar to Ostwald ripening on the $\mathrm{Au}$ /iron oxide catalysts is probably owing to the interaction between $\mathrm{Au}$ and the $\mathrm{CO}$ component. The large particles grow at the expense of the small ones in the $\mathrm{Au} / \mathrm{FeO}_{x}$ catalyst possibly owing to the interparticle transport of the $\mathrm{Au}(\mathrm{CO})_{x}$ mobile species. Herein, a new insight into the metal-support interaction of $\mathrm{Au} /$ iron oxide catalysts by combining the traditional characterizations used previously and a gas phase IL-TEM method is obtained, which offers valuable guidance to the rational design of new generation catalysts.

\section{References}

[1] A. Stephen, K. Hashmi, G. J. Hutchings, Angew. Chem. Int. Ed., 2006, 45, 7896-7936.

[2] M. Haruta, T. Kobayashi, H. Sano, N. Yamada, Chem. Lett., 1987, 405-408.

[3] B. Shao, Y. Y. Zhang, J. H. Huang, B. T. Qiao, Y. Su, S. Miao, Y. Zhou, D. Li, W. X. Huang, W. J. Shen, Small Methods, 2018, 2, 1800273.

[4] Y. Guo, D. Gu, Z. Jin, P. P. Du, R. Si, J. Tao, W. Q. Xu, Y. Y. Huang, S. Senanayake, Q. S. Song, C. J. Jia, F. Schuth, Nanoscale, 2015, 7, 4920-4928.

[5] S. Hu, W. Xiao, W. W. Yang, J. Yang, Y. R. Fang, J. X. Xiong, Z. Luo, H. T. Deng, Y. B. Guo, L. Z. Zhang, J. Ding, ACS Appl. Mater. Interfaces, 2018, 10, 17167-17174.
[6] F. Kettemann, S. Witte, A. Birnbaum, B. Paul, G. Clavel, N. Pinna, K. Rademann, R. Kraehnert, J. Polte, ACS Catal., 2017, 7, 8247-8254.

[7] L. F. Allard, A. Borisevich, W. L. Deng, R. Si,M. Flytzani-Stephanopoulos, S. H. Overbury, J. Electron Microsc., 2009, 58, 199-212.

[8] M. M. Schubert, S. Hackenberg, A. C. van Veen, M. Muhler, V. Plzak, R. J. Behm, J. Catal., 2001, 197, 113-122.

[9] S. Najafishirtari, P. Guardia, A. Scarpellini, M. Prato, S. Marras, L. Mannaa, M. Colombo, J. Catal., 2016, 338, 115-123.

[10] S. L. Chen, L. F. Luo, Z. Q. Jiang, W. X. Huang, ACS Catal., 2015, 5, 1653-1662.

[11] [11] S. Lee, C. Y. Fan, T. P. Wu, S. L. Anderson, J. Am. Chem. Soc., 2004, 126, 5682-5683.

[12] D. C. Meier, D. W. Goodman, J. Am. Chem. Soc., 2003, 126, 1892-1899.

[13] M. Haruta, Faraday Discuss, 2011, 152, 11-32.

[14] S. H. Overbury, V. Schwartz, D. R. Mullins, W. F. Yan, S. Dai, J. Catal., 2006, 241, 56-65.

[15] M. Khoudiakov, M. C. Gupta, S. Deevi, Appl. Catal. A, 2005, 291, 151-161.

[16] M. Haruta, S. Dsubota, T. Kobayashi, H. Kageyama, M. J. Genet, B. Delmon, J. Catal., 1993, 144, 175-192.

[17] C. W. Han, T. Choksi, C. Milligan, P. Majumdar, M. Manto, Y. R. Cui, X. H. Sang, R. R. Unocic, D. Zemlyanov, J. Greeley, C. Wang, J. Greeley, V. Ortalan, Nano Lett., 2017, 17, 4576-4582.

[18] S. Gatla, D. Aubert, G. Agostini, O. Mathon, S. Pascarelli, T. Lunkenbein, M. G. Willinger, H. Kaper, ACS Catal., 2016, 6, 6151-6155.

[19] H. L. Tang, F. Liu, J. K. Wei, B. T. Qiao, K. F. Zhao, Y. Su, C. Z. Jin, L. Li, J. Y. (Jimmy) Liu, J. H. Wang, T. Zhang, Angew. Chem. Int. Ed., 2016, 55, 10606-10611.

[20] D. I. Enache, J. K. Edwards, P. Landon, B. Solsona-Espriu, A. F. Carley, A. A. Herzing, M. Watanabe, C. J. Kiely, D. W. Knight, G. J. Hutchings, Science, 2006, 311, 362-365.

[21] M. Comotti, W. C. Li, B. Spliethoff, F. Schuth, J. Am. Chem. Soc., 2006, 128, 917-924.

[22] P. Schlexer, D. Widmann, R. J. Behm, G. Pacchioni, ACS Catal., 2018, 8, 6513-6525.

[23] S. D. Xu, H. X. Li, J. Du, J. H. Tang, L. Wang, ACS Sustain. Chem. Eng., 2018, 6, 6418-6424.

[24] S. T. Daniells, A. R. Overweg, M. Makkee, J. A. Moulijn, J. Catal., 2005, 230, 52-65.

[25] T. Yan, D. W. Redman, W. Y. Yu, D. W. Flaherty, J. A. Rodriguez, C. B. Mullins, J. Catal., 2012, 294, 216-222.

[26] H. Ha, S. Yoon, K. An, H. Y. Kim, ACS Catal., 2018, 8, 11491-11501.

[27] X. J. Wei, B. Shao, Y. Zhou, Y. Li, C. Jin, J. Y. Liu, W. J. Shen, Angew. Chem. Int. Ed., 2018, 57, 11289-11293.

[28] L. Li, A. Wang, B. Qiao, J. Lin, Y. Q. Huang, X. D. Wang, T. Zhang, J. Catal., 2013, 299, 90-100.

[29] A. A. Herzing, C. J. Kiely, A. F. Carley, P. Landon, G. J. Hutchings, Science., 2008, 321, 1331-1335.

[30] I. X. Green, W. J. Tang, M. Neurock, J. T. Yates Jr., Science, 2011, 333, 736-739.

[31] X. Y. Liu, M. H. Liu, Y. C. Luo, C. Y. Mou, S. D. Lin, H. K. Cheng, J. M. Chen, J. F. Lee, T. S. Lin, J. Am. Chem. Soc., 2012, 134, 10251-10258.

[32] Y. Wang, D. Widmann, M. Heenemann, T. Diemant, J. Biskupek, R. Schlögl, R. J. Behm, J. Catal., 2017, 354, 46-60.

[33] Y. Suchorski, S. M. Kozlov, I. Bespalov, Z. Budinska, M. Datler, D. Vogel, K. M. Neyman, G. Rupprechter, Nat. Mater., 2018, 17, 519-522.

[34] Z. Y. Duan, G. Henkelman, ACS Catal., 2018, 8, 1376-1383. 
[35] I. Ro, I. B. Aragao, J. P. Chada, Y. Y. Liu, K. R. R. Dones, M. R. Ball, D. Zanchet, J. A. Dumesic, G. W. Huber, J. Catal., 2018, 358, 19-26.

[36] Y. S. Ma, L. Y. Zhang, W. Shi, Y. M. Niu, B. S. Zhang, D. S. Su, Chin. Chem. Lett., 2019, 30, 183-186.

[37] D. S. Su, B. S. Zhang, R. Schlögl, Chem. Rev., 2015, 115, 8, 2818-2882.

[38] Z. C. Canbek, R. Cortes-Huerto, F. Testard, O. Spalla, S. Moldovan, O. Ersen, A. Wisnet, G. Wang, J. Goniakowski, C. Noguera, N. Menguy, Cryst. Growth Des., 2015, 15, 3637-3644.

[39] S. P. Cho, M. A. Bratescu, N. Saito, O. Takai, Nanotechnology, 2011, 22, 455701, 1-7.

[40] G. Corro, S. Cebada, U. Pal, J. L. G. Fierro, J. Catal., 2017, 347, 148-156.

[41] A. A. Zhang, L. Zhang, G. J. Jing, H. Zhang, S. Wang, H. Q. Su, S. H. Zeng, Int. J. Hydrogen Energy, 2018, 43, 10322-10333.

[42] J. C. Dupin, D. Gonbeau, P. Vinatierb, A. Levasseur, Phys. Chem. Chem. Phys., 2000, 2, 1319-1324.

[43] G. J. Hutchings, M. S. Hall, A, F. Carley, B. E. Solsona, C. J. Kiely, A. Herzing, M. Makkee, J. A. Moulijn, A. Overweg, J. C. Fierro-Gonzalez, B. C. Gates, J. Catal., 2006, 242, 71-81.

[44] L. P. Zeng, K. Z. Li, H. Wang, H. Yu, X. Zhu, Y. G. Wei, P. H. Ning, C. Z.
Shi, Y. M. Luo, J. Phys. Chem. C, 2017, 121, 12696-12710.

[45] L. Wolski, I. Sobczak, M. Ziolek, J. Catal., 2017, 354, 100-112.

[46] Y. P. Zhai, D. Pierre, R. Si, W. L. Deng, P. Ferrin, A. U. Nilekar, G. W. Peng, J. A. Herron, D. C. Bell, H. Saltsburg, M. Mavrikakis, M. Flytzani-Stephanopoulos, Science, 2010, 329, 1633-1636.

[47] G. X. Chen, Y. Zhao, G. Fu, P. N. Duchesne, L. Gu, Y. P. Zheng, X. F. Weng, M. S. Chen, P. Zhang, C. W. Pao, J. F. Lee, N. F. Zheng, Science, 2014, 344, 495-499.

[48] M. Yang, S. Li, Y. Wang, J. A. Herron, Y. Xu, L. F. Allard, S. Lee, J. Huang, M. Mavrikakis, M. Flytzani-Stephanopoulos, Science, 2014, 346, 1498-1501.

[49] J. C. Meier, I. Katsounaros, C. Galeano, H. J. Bongard, A. A. Topalov, A. Kostka, A. Karsarolinachin, F. Schuth, K. J. J. Mayrhofer, Energy Environ. Sci., 2012, 5, 9319-9330.

[50] W. Shi, B. S. Zhang, Y. M. Lin, Q. Wang, Q. Zhang, D. S. Su, ACS Catal., 2016, 6, 7844-7854.

[51] Masliuka, M. Swobodaa, G. A. Sillera, R. Schlögla, T. Lunkenbeina, Ultramicroscopy, 2018, 195, 121-128.

[52] A. Baldan, J. Mater. Sci., 2002, 37, 2171-2202.

[53] T. W. Hansen, A. T. Delariva, S. R. Challa, A. K. Datye, Acc. Chem. Res., 2013, 46, 1720-1730.

\section{Graphical Abstract}

Chin. J. Catal., 2019, 40: 1884-1894 doi: S1872-2067(19)63374-7

\section{Tailoring the surface structures of iron oxide nanorods to support Au nanoparticles for CO oxidation}

Wen Shi ${ }^{\dagger}$, Tongtong Gao ${ }^{\dagger}$, Liyun Zhang, Yanshuang Ma, Zhongwen Liu*, Bingsen Zhang*

Institute of Metal Research, Chinese Academy of Sciences; Shaanxi Normal University; University of Science and Technology of China

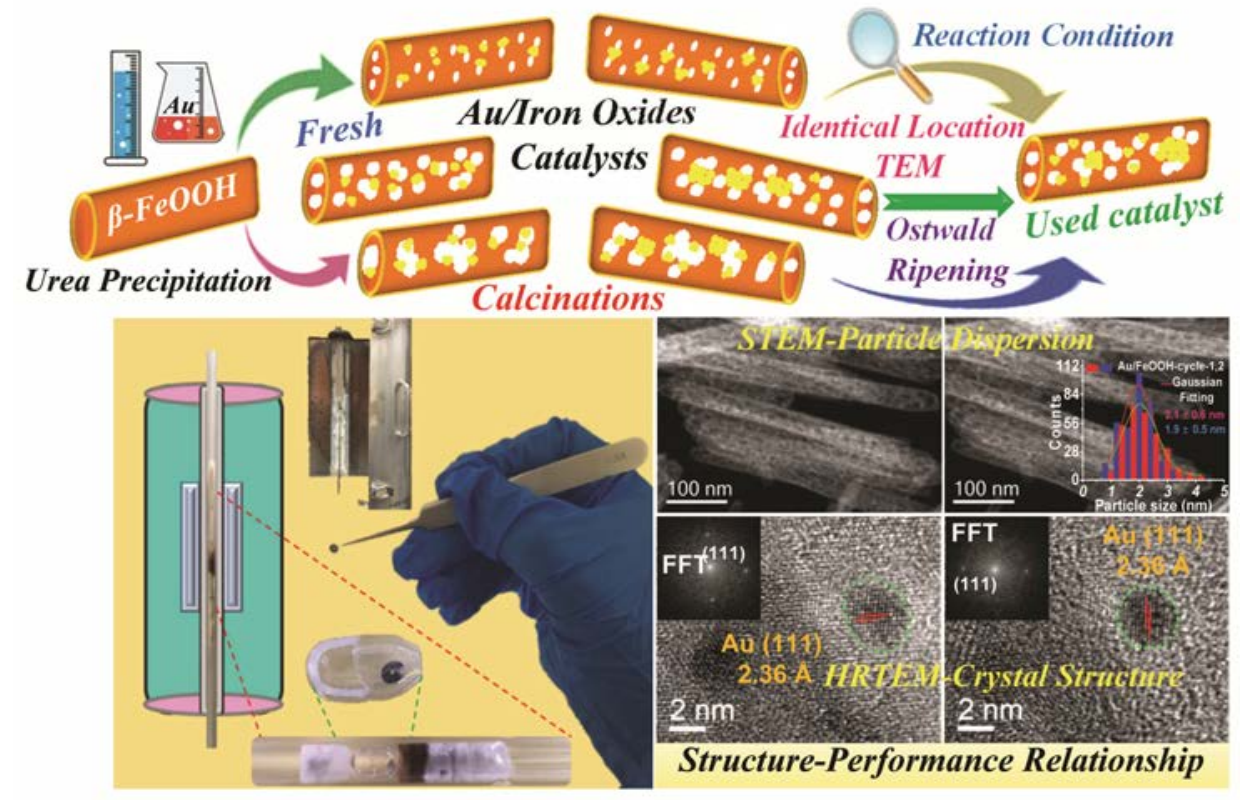

Iron oxides with varied surface properties were synthesized by the calcination of the $\beta$-FeOOH precursor at different temperatures; the iron oxides were further used as supports for Au NPs to obtain a Au/iron oxide series of catalysts. The correlation between the iron oxides with varied surface properties and supported Au NPs in CO oxidation was established after detailed characterizations. Moreover, the structure evolution of the iron oxide supported Au NPs catalysts during the CO oxidation was studied by the gas-phase identical location transmission electron microscopy (IL-TEM) method. By comparing and quantifying a series of TEM images, the behavior of the supported $\mathrm{Au}$ NPs under certain reaction conditions, and the relation between the structure evolution of the catalysts and the surface properties were further explored. 
[54] F. Yang, M. S. Chen, D. W. Goodman, J. Phys. Chem C, 2009, 113, 254-260.

[55] S. C. Parker, C. T. Campbell, Phys. Rev. B, 2007, 75,
035430/1-035430/15.

[56] S. C. Parker, C. T. Campbell, Top. Catal., 2007, 44, 3-13.

\title{
铁氧化物纳米棒负载金纳米颗粒催化剂载体表面结构调控对CO氧化的影响
}

\author{
石 文 $^{\mathrm{a}, \mathrm{c}, \dagger}$, 高䑣䑣 ${ }^{\mathrm{a}, \mathrm{b}, \dagger}$, 张历云 ${ }^{\mathrm{a}}$ ，马彦爽，刘忠文, ${ }^{\mathrm{b},}$, 张炳森 ${ }^{\mathrm{a}, \#}$ \\ a 中国科学院金属研究所沈阳材料科学国家研究中心, 辽宁沈阳 110016 \\ b陕西师范大学化学化工学院, 陕西省合成气转化重点实验室, 陕西西安710119 \\ c中国科学技术大学材料科学与工程学院, 安徽合肥 230026
}

\begin{abstract}
摘要: 自1987年Haruta等首次发现氧化物负载金催化剂具有优异的低温催化CO氧化活性以来, 纳米金催化剂由于其独特 的物理化学性质引起了催化科学工作者的极大兴趣. 大量研究致力于揭示金纳米颗粒的尺寸、价态、制备方法以及活化 过程对其低温催化 $\mathrm{CO}$ 氧化的性能影响机制. 在众多的负载型金催化剂体系中, 可还原性金属氧化物负载Au纳米粒子催化 剂由于能产生较强的金属-载体相互作用(SMSI)或做为助催化剂组分提供氧活化位点而受到广泛研究. 其中, 铁氧化物负 载金被认为是最具有潜力的低温催化 $\mathrm{CO}$ 氧化反应催化剂之一; 研究表明, 其催化性能不仅取决于金纳米粒子的尺寸, 而且 在很大程度上取决于氧化铁载体的表面性质. 尽管氧化铁负载的金催化剂具有非常高的活性, 并很好地从传统的动力学 角度解释了其反应机理, 但氧化铁的表面性质对负载金属-载体间的界面相互作用及反应性能的影响机制仍存在争议, 尤 其是针对氧化铁表面性质对负载金纳米粒子分散性和稳定性影响的研究仍相对较少, 并且缺少直观的研究手段. 基于此, 本文将预先制备的 $\beta-\mathrm{FeOOH}$ 前驱体在不同温度氞气气氛中焙烧处理, 制备具有不同表面性质的铁氧化物纳米棒, 然后负载 $\mathrm{Au}$ 纳米粒子, 并应用于 $\mathrm{CO}$ 氧化反应. 进一步利用X射线衍射(XRD)、透射电子显微镜(TEM)和X射线光电子能谱(XPS)等表 征手段对Au纳米粒子与氧化铁载体间的相互作用进行了细致表征, 揭示了不同氧化铁表面性质对负载金纳米粒子的分散 性、化学态的影响以及在一氧化碳氧化反应中的活性和稳定性的差异原因.

TEM结果表明, 焙烧前不同氧化铁载体上的Au纳米粒子均高度分散, 且颗粒尺寸相近, 平均粒径约为 $1.0 \mathrm{~nm}$; 焙烧后 不同载体上的 $\mathrm{Au}$ 纳米粒子尺寸均有不同程度的长大. 粒径统计结果显示, $\mathrm{FeOOH}$ 载体表面 $\mathrm{Au}$ 纳米粒子的平均粒径尺寸约 为 $2.5 \mathrm{~nm}$, 且以面心立方结构的单晶形式存在; 而 $\mathrm{FeO}_{x}$ 和 $\alpha-\mathrm{Fe}_{2} \mathrm{O}_{3}$ 载体表面的 $\mathrm{Au}$ 纳米粒子的平均粒径尺寸则分别为 3.9 和 3.5 $\mathrm{nm}$, 且存在大量多重孪晶结构. 结合XPS和性能测试结果发现, 焙烧前 $\mathrm{Au} / \mathrm{FeOOH}$ 催化剂表面的羟基有助于带正电的 $\mathrm{Au}$ 吸 附和解离氧气, 从而具有低温 $\mathrm{CO}$ 氧化反应活性, 但长时间的稳定性测试表明, 反应条件下 $\mathrm{FeOOH}$ 表面羟基不稳定, 会逐渐 脱除, 从而导致催化活性下降. 将催化剂预先在 $200{ }^{\circ} \mathrm{C}$ 空气中焙烧, 不同氧化铁载体上金的化学状态会由金属阳离子部分 转变为零价金, 同时伴随着载体表面羟基的消失. 其中, $\mathrm{FeOOH}$ 表面含有高于其它铁氧化物的 $\mathrm{Au}^{0}$, 且 $\mathrm{Au} / \mathrm{FeOOH}$ 催化剂表 现出对 CO最优的反应性能和较好的稳定性, 说明焙烧处理后催化剂的反应性能与小尺寸的零价金物种密切相关.

此外, 我们还将相同位置-电子显微学方法(IL-TEM)应用于气相反应体系中, 探索了金/铁氧化物系列催化剂的结构演 变. 结果表明, 相比于 $\mathrm{Au} / \mathrm{FeOOH}$ 和 $\mathrm{Au} / \alpha-\mathrm{Fe}_{2} \mathrm{O}_{3}, \mathrm{FeO}_{x}$ 载体表面独特的孔结构使负载于其上的 $\mathrm{Au}$ 纳米粒子在反应条件下会 发生明显的类奥斯特瓦尔德熟化行为, 并通过改变反应气中 $\mathrm{CO}$ 和 $\mathrm{O}_{2}$ 的计量比推测该过程可能是由于 $\mathrm{Au}$ 与 $\mathrm{CO}$ 组分相互作 用导致, 从而揭示了长时间反应条件下其催化CO氧化活性下降的原因. 本文通过结合传统的表征手段和气相IL-TEM方 法, 对金/铁氧化物催化剂的金属-载体相互作用进行了直观研究, 并为新型催化剂的开发和设计提供了参考.
\end{abstract}

关键词: 铁氧化物纳米棒; 表面结构; 金纳米颗粒; 一氧化碳氧化; 结构演变

收稿日期: 2019-03-02. 接受日期: 2019-04-06. 出版日期: 2019-12-05.

*通讯联系人. 电话: (029)81530801; 传真: (029)81530727; 电子信箱: zwliu@snnu.edu.cn

\#通讯联系人. 电话: (024)83970027; 传真: (024)83970019; 电子信箱: bszhang@imr.ac.cn 基金来源：国家自然科学基金(21773269，21761132025，91545119，21703262); 中国科学院青年创新促进会(2015152); 辽宁省自 然科学基金和沈阳材料科学国家研究中心联合基金(20180510047).

本文的电子版全文由Elsevier出版社在ScienceDirect上出版(http://www.sciencedirect.com/science/journal/18722067). 